\title{
Ukraine mellem Rusland og Nato
}

Jurij Jekhanurov

\section{Med udgangspunkt i Ruslands håndtering af pro- blemerne i Kaukasus og FN's manglende indfly- delse må man konkludere, at Ukraine kun kan opnå sikkerhed gennem medlemskab af EU og NATO}

De seneste begivenheder i Kaukasus har vist, at forsøg på at løse fastfrosne konflikter med brug af militære midler har en negativ indvirkning på sikkerhedssituationen ikke alene i regionen selv, men i hele det europæiske rum.

Den Kolde Krigs endeligt og Sovjetunionens sammenbrud er den største historiske begivenhed i de sidste 25 år af det 20. århundrede. Nye, uafhængige stater stod over for den opgave selv at skulle fastlægge deres udenrigs- og sikkerhedspolitik med forståelse for det historiske ansvar over for eget folk. Det gjaldt om at nå frem til den mest effektive sikring af egen, national sikkerhed og forsvar af nationale interesser, og denne proces fortsætter.

Nogle stater har allerede løst den- ne opgave og kan føle sig tilstrækkelig sikre og beskyttede i de kollektive sikkerhedssystemer, andre stater er enten i færd med at opbygge deres eget sikkerhedssystem baseret på egne kapaciteter eller har endnu ikke truffet et valg mellem disse optioner.

I historisk og geopolitisk henseende befinder Ukraine sig mellem to forskellige civilisationer, den europæiske og den euroasiatiske. Den britiske geopolitker John Mackinder har beskrevet Ukraine som værende et 'Heartland', der befinder sig i Europas centrum og har en afgørende geografisk placering i forhold til at opnå stabilitet på dette kontinent.

Trods en kompliceret og dramatisk historie har det ukrainske folk ikke mistet sin europæiske identitet, 
og det har truffet et civilisatorisk valg til fordel for en europæisk og dermed demokratisk model for landets udvikling. Integration i de europæiske og euroatlantiske strukturer har været og er fortsat en prioriteret retning i vores politik fra 2003, hvor denne kurs først blev lagt fast ved en beslutning af Det Nationale Sikkerheds- og Forsvarsråd i Ukraine, og senere i "Lov om Ukraines nationale sikkerhed", Militærdoktrinen og Ukraines Nationale Sikkerhedskoncept.

\section{Partner med Rusland ...}

\section{Den Russiske Føderation er vores} store nabo og strategiske partner. Vi har fælles historie, religion, kultur og traditioner, samt omfattende økonomiske relationer og er altså afhængige af hinanden. Ruslands vigtigste, økonomiske forbindelser til Europa går netop gennem Ukraine. 80 pct. af den gas, som Rusland eksporterer til Europa sendes gennem Ukraine. De ukrainske havne benyttes intensivt af russiske firmaer, og samtidig er ukrainske og russiske virksomheder, ikke mindst producenter af militært materiel, bundet sammen af tætte produktionsmæssige relationer. Fx foretager vi prøveaffyringer af vores luftværnssystemer på russiske øvelsesområder, og vi samarbejder om fremstilling af blandt andet det militære transportfly Antonov-70.

Vi har indgået aftaler om Rus- lands Sortehavsflådes passage af Ukraines statsgrænse, samt tilstedeværelse af dens enheder på ukrainsk område. Kravene heri svarer til gældende aftaler om Den Russiske Føderations Sortehavsflådes midlertidige baserettigheder på Ukraines territorium. Hidtil har den russiske Sortehavsflåde opfyldt disse krav. Alt dette er vores fælles, geopolitiske gods, som vi skal beskytte og styrke. Derfor vil jeg gerne gentage, at Rusland er og vedbliver med at være vores strategiske partner.

\section{... med ansigtet vendt mod vest}

Samtidig er den euroatlantiske retning Ukraines valg i civilisatorisk henseende og den strategiske kurs for landets udvikling: Da Ukraine i begyndelsen af 1992 blev medlem af North-Atlantic Partnership Council (NAPC), indledte man en militær og politisk dialog med NATO. I 1994 sluttede Ukraine sig til rammeaftalen om Partnership for Peace (PfP). På NATO-topmødet i Madrid i juli 1997 underskrev den ukrainske præsident 'Charter on a Distinctive Partnership' mellem NATO og Ukraine, hvori man nedfældede parternes politiske forpligtelse på højeste niveau til at udvikle et 'særligt og effektivt' partnerskab, som skal bidrage til at skabe stabilitet i denne region. Denne aftale danner grundlaget for konsultationer mellem NATO og Ukraine i en euroatlantisk sikkerhedssammenhæng. 
I dag er ukrainsk økonomi ude af den krise, som indtraf i forbindelse med Sovjetunionens opløsning. I 2007 voksede landets BNP med $7,6 \%$. Omfanget af direkte udenlandske investeringer steg med $36,5 \%$ og udgør nu 29,5 mia. USD.

Alle disse resultater skal beskyttes. Derfor er den unge, ukrainske stat meget opmærksom på spørgsmålet om den nationale sikkerhed, og vi undlader at indgå aftaler, som ville bringe os tilbage til de relationer, der eksisterede i fortidens Sovjetunion. Derfor er Ukraine kun deltager i CIS/SNG (Sammenslutningen af Uafhængige Stater) og ikke medlem, og Ukraine er heller ikke medlem af CSTO/ODKB (Den Kollektive Sikkerhedsaftaleorganisation).

\section{Udfordringer og trusler}

Vi har meget omhyggeligt vurderet risici og trusler mod vor nationale sikkerhed. Disse er beskrevet næsten tilsvarende hos vore naboer. Før august 2008 har vi især set følgende udfordringer og trusler inden for sikkerhed og forsvar:

- andre staters forsøg på indblanding $\mathrm{i}$ interne ukrainske anliggender;

- militær/politisk ustabilitet og regionale og lokale krige/konflikter nær Ukraines grænser;

- spredning af masseødelæggelsesvåben og disses fremføringsmidler; - organiseret kriminalitet og terrorisme;

- illegal migration.
Herudover har ledende russiske politikeres retorik, som konstant skærpes i relation til Krim og Sevastopol, dens utilslørede, anti-ukrainske karakter i kombination med et økonomisk og politisk pres på Ukraine, givet grund til at overveje om at udvide denne liste over potentielle trusler.

Begivenhederne, som har fundet sted og fortsat udspiller sig i Kaukasus, har stillet Ukraine over for nye udfordringer og trusler.

For det første: En trussel om hårdt, politisk pres og om militær indblanding, en trussel om støtte udefra til radikalisme og separatisme og i den sidste ende en trussel om brud på Ukraines territoriale integritet.

For det andet: En reel fare for, at Ukraine inddrages i en mellemnational konflikt på grund af manglende lovmæssigt aftalegrundlag angående brugen af den på ukrainsk område baserede russiske Sortehavsflåde i væbnede konflikter. I denne sammenhæng kan jeg oplyse, at der på bilateralt niveau er principiel enighed om at indgå en sådan aftale. Men den russiske part har hidtil ikke godkendt det ukrainske forslag og ej heller fremsendt sit eget.

For det tredje: Risikoen ved at Ruslands militære og politiske ledelse har vist sig parat til at blande sig $\mathrm{i}$ nabolandenes interne anliggender og gribe til anvendelsen af militære magtmidler under påberåbelse af 'at komme egne borgere til hjælp'.

Ukraine hører til de lande, der 
værdsætter tilbageholdenhed og ikke går ind for at reagere overdrevent følelsesladet på provokationer. Det må med beklagelse konstateres, at den væbnede konflikt på Georgiens territorium og Den Russiske Føderations inadækvate optræden i selve kampfasen, har ført til en uundgåelig skærpelse af forholdet mellem Ukraine og Rusland.

I dag er realiteten bag truslen mod Ukraines territoriale integritet og suverænitet tydeligere end nogenside. Den hidtidige vurdering har været, at der ikke eksisterer en sådan trussel på mellemlangt sigt; men den svarer ikke længere til virkeligheden. En analyse af situationen, som den tegner sig efter konflikten, gør det muligt at drage nogle foreløbige konklusioner angående hele det europæiske rums sikkerhed.

For det første: Krænkelsen af Georgiens territoriale integritet gennem anvendelse af væbnede styrker og landets de facto tab af en del af dets territorium har affødt en ny, negativ præcedens for løsning af såkaldte fastfrosne konflikter. Helsinki-principperne fra 1975 er blevet brudt af en stat, som er permanent medlem af FN's Sikkerhedsråd, Samtidig har FN demonstreret sin manglende evne til at finde en løsning på den væbnede konflikt.

For det andet: De førende, europæiske landes energimæssige afhængighed af Rusland har begrænset deres muligheder for at reagere ad- ækvat på den russiske ledelses handlinger og for at have effektiv indflydelse på situationen.

For det tredje: Den Russiske Føderations Sortehavsflådes basering og manglen på koordinerede planer for dens tilbagetrækning inden maj 2017 er en trussel mod Ukraines nationale interesser.

Med udgangspunkt i ovenstående må man drage den logiske konklusion, at garanti for Ukraines sikkerhed kun kan opnås gennem medlemskab af EU og NATO.

\section{På vej mod NATO}

Foreløbig er Ukraine dog ikke medlem af noget kollektivt sikkerhedssystem og må derfor selv sørge for sin militære sikkerhed. Men samarbejdet med NATO gør det muligt at forbedre vores evne til at løse forsvarsmæssige opgaver. Det er i øvrigt primært koncentreret på områder, som skal bidrage til at opfylde kriterierne for medlemskab af NATO.

I rammerne af den såkaldte Planning and Review Proces (PARP) arbejdes der frem mod forøget interoperabilitet af enheder på taktisk niveau og af elementer i den militære føringsstruktur med NATO-medlemslandenes tilsvarende komponenter. I de væbnede styrker er nitten ukrainske enheder udpeget til at indgå i Planning and Review Processen. Den indhøstede erfaring gør, at vi kan deltage i NATO-ledede operationer. Det totale antal militærperso- 
ner, som deltager i operationer og missioner i udlandet udgør ca. 600.

Vi er i gang med at optimere de væbnede styrkers militære kommandosystem. Vi har oprettet en såkaldt Joint Operational Command, som allerede nu leder de enheder, der løser opgaver uden for landets grænser. Eksisterende våbensystemer $\mathrm{og}$ materiel moderniseres og opgraderes, og der anskaffes nye typer militært materiel og udstyr.

Trods vore finansielle problemer arbejder vi frem mod at overgå til udelukkende professionel bemanding af de væbnede styrker, samtidig med at vi vil indføre en form for tjeneste i en militær reserve. Indtil nu har vi uddannet ca. 2000 reservister til mobilisering. Dette står i skarp kontrast til 1990'erne, hvor der i Ukraine var en million af disse reservister.

Vi arbejder på at styrke den civile, demokratiske kontrol med landets væbnede styrkers aktiviteter. Forsvarsministeriet har tilknyttet et såkaldt Borgerråd, i hvilket der sidder repræsentanter for mere end 90 forskellige civile organisationer og massemedier. Forsvarsministeriet udgiver hvert år en oversigt med titlen "Hvidbog om Ukraines forsvarspolitik". Den findes også på engelsk og er tilgængelig via internettet.

(http://www.mil.gov.ua/files/white_boo k/white_book_en2007.pdf).

I særlig grad skal det understreges, at Ukraine ikke blot er forbruger, men også leverandør af sikker- hed $\mathrm{i}$ regionen og i verden.

- Vi deltager i samtlige NATO-operationer uden undtagelse, og vi er ved at forøge antallet af udsendte til ISAF i Afghanistan.

- Ukraines væbnede styrker er parat til at samarbejde med NATO om at øge deres bidrag til NATOs kapaciteter. Ukraine indgår i det fælles britisk-franske helikopterinitiativ. Vi er rede til at stille vore reparationsvirksomheder for fly og helikoptere til rådighed for partnerlandene. Det ukrainske flyvevåben er klar til at levere ydelser inden for strategisk lufttransport af gods og personel. Der foregår allerede forhandlinger om aftaler om lufttransportstøtte til de enkelte medlemslande i NATO med indsættelse af flyvevåbnets transportflystyrke.

- Ifølge alliancens beslutning indgik Ukraine i juli 2008 i NATO Response Force, hvilket giver Ukraine mulighed for at øge sit bidrag til det euroatlantiske, kollektive sikkerhedssystem. Deltagelsen i NATO Response Force er et udtryk for tillid til Ukraines væbnede styrker fra alliancens side, og for Ukraines vilje til at påtage sig en forpligtelse.

Jeg kan ikke undlade at komme ind på spørgsmålet om Ukraines ønske om en Membership Action Plan (MAP). Ukraines tilnærmelse til NATO er ikke vendt mod Den Russiske Føderation eller noget tredjeland i det hele taget. Som alle andre medlemslande i NATO ønsker Ukraine at udvikle gode, gensidigt udbyt- 
terige naborelationer med Rusland. Vi foreslår Rusland en åben dialog. Et ukrainsk medlemskab af alliancen vil kun befordre udviklingen af de bilaterale relationer med Rusland og tjene til at styrke den europæiske sikkerhed. Andre eksempler herpå er Tyskland, Bulgarien og Danmark selv.

\section{Endnu flere forberedelser}

Beslutningerne på topmødet i Bukarest, hvor Ukraine fik et klart signal vedrørende muligheden for at opnå medlemskab af NATO, har sat yderligere fart i vores bestræbelser på at reformere de væbnede styrker. Der er følgende prioriteter i udførelsen af denne opgave:

- Øge effektiviteten i den militære ledelses- og føringsstruktur og i den taktiske uddannelse, nå et højt beredskab for enheder i landets Joint Rapid Reaction Force til at løse opgaver i overensstemmelse med dennes formål, samt sikre, at luftværnsenheder i beredskab omkring særlig vigtige objekter fungerer optimalt. - Sikre en effektiv bemanding af de væbnede styrker på kontraktbasis, samt indføre tjeneste i en såkaldt militær reserve.

- Holde militært materiel og udstyr i kampduelig stand, samt løbende at forny dette og udvikle innovative teknologier.

- Fritage de væbnede styrkers enheder for opgaver, der ikke er i overensstemmelse med deres funktion, såsom vedligeholdelse af overflødigt materiel og udstyr, uskadeliggørelse og genanvendelse af overskydende ammunition, som ikke længere kan anvendes eller opbevares, komponenter til missilbrændstof og militær ejendom, samt bevogtning af forladte kaserneområder.

- Sikre, at man kan yde det militære personel og deres familiemedlemmer lovbestemte sociale garantier.

I dag arbejder vi på at løse disse opgaver og takker de NATOmedlemslande, som støtter os i denne proces.

Ukraine vil gøre alt for, at den første evaluering af landets fremskridt, som alliancens medlemslandes udenrigsministre skal foretage i december i år, også bliver den sidste, således at Ukraine bliver inviteret til at indlede en MAP (Membership Action Plan) inden udgangen af 2008. Ukraine er et ungt, europæisk demokrati, som allerede yder et betydeligt bidrag til sikkerheden i det euroatlantiske rum. Dets fremtidige fuldgyldige medlemskab af alliancen vil kun styrke NATO og medvirke til øget sikkerhed i regionen.

Artiklen er en lettere bearbejdet udgave af en tale, som den ukrainske forsvarsminister Jurij Jekhanurov holdt i Det Udenrigspolitiske Selskab den 11.09.2008 i København.

Oversat fra ukrainsk af Claus Mathiesen, Institut for Sprog, Forsvarsakademiet. 